\title{
DOING BUSINESS ON THE INTERNET: INSIGHTS FROM INFORMATION SYSTEMS AND ORGANIZATIONAL THEORY RESEARCH
}

\author{
Catherine Middleton \\ cmiddlet@bus.yorku.ca \\ Schulich School of Business \\ York University
}

Working Paper 19-97

An abstracted version of this paper has been published as:

Middleton, C. A. (1997). Doing Business on the Internet: Insights from Information Systems and Organizational Theory Research. In J. N. D. Gupta (Ed.), Proceedings of the Americas Conference on Information Systems, (pp. 263-265). Indianapolis: Association for Information Systems.

http://hsb.baylor.edu/ramsower/ais.ac.97/papers/middleto.htm 


\title{
DOING BUSINESS ON THE INTERNET: INSIGHTS FROM INFORMATION SYSTEMS AND ORGANIZATIONAL THEORY RESEARCH
}

\author{
Catherine Middleton \\ Schulich School of Business \\ York University \\ Working Paper
}

\section{INTRODUCTION}

The Internet is becoming an essential communication tool for North American businesses, but to date there has been little research on the expected impacts of using the Internet in a business context. This paper will examine theories of communications, information systems, and organizations, in order to understand what existing research can offer to businesses venturing onto the Internet. It will note lessons that can be learned from previous adoptions of new technologies, and identify instances where existing theory does not inform business use of the Internet and its associated new communication technologies ${ }^{1}$.

The number of businesses and individuals using the Internet has been growing exponentially for several years (Bell \& Gemmell, 1996; Churbuck, 1994; Cortese, 1995; Jennings, 1996; Rasmussen, 1996; Wilder, 1996a). For

\footnotetext{
${ }^{1}$ Four key features distinguish new electronic communication technologies from existing communication technologies. These are i) high level capacity for data storage and transmission speed, combined with easy access to stored data; ii) creation of a new shared space in which communication can occur, enabling contact between individuals and groups who might otherwise have never communicated; iii) capacity for widespread idea dissemination or targeted communication, combined with interactivity and multidirectional information flows; and iv) improved communication abilities over time and space, rendering geographic location unimportant (Middleton, 1997). The Internet offers all these features to its users.
} 
many businesses, the question is no longer whether to get on the Internet, but when and how to do so (Currid, 1995). Indeed, despite surveys showing that only a small percentage of the population has Internet access (e.g. a recent Statistics Canada survey estimated that $7.4 \%$ of Canadian households use the Internet from home [Mitchell, 1996]), businesses continue to flock to the Internet in record numbers (Violino, 1996).

While the business community has rapidly adopted the Internet and its related technologies, the academic community has been somewhat slower in using the new technologies, and in undertaking serious study of the implications of the rapid technological changes now occurring. Organization theorists have been studying the impacts of introducing simple communication tools like e-mail (McKenney, 1988; Sproull \& Kiesler, 1986), but little work has yet been published that looks specifically at the organizational impacts of using the Internet.

The computer science research community has produced a significant volume of work on technical issues related to the Internet. For example, Communications of the ACM has covered Internet technology (August 1994) ATM networks (February 1995), electronic commerce (June 1996) and securing cyberspace (November 1994), but this research does not explicitly consider the challenges businesses face in using the Internet.

Information systems (IS) researchers are investigating electronic commerce $^{2}$, producing electronic versions of journals (e.g. Management Information Systems $Q$ Quarterly ${ }^{3}$ ), and making conference registration and

\footnotetext{
${ }^{2}$ See http://www-iwi.unisg.ch/iswnet/ec-em.html, http://www.cox.smu.edu/isworld/ecourse/home.html, and http://www.engr.iupui.edu/ ho/interests/commmenu.html for examples.

${ }^{3}$ http://www.cox.smu.edu/mis/misq/central.htm
} 
proceedings available through the World Wide Web (WWW) (e.g. Association of Information Systems Americas Conference ${ }^{4}$ ). As might be expected, much of the academic work on electronic commerce is being disseminated through new means, such as the web, without appearing in more traditional academic forums. No doubt this is due in part to long lead times in academic publishing, but it serves to highlight the inadequacy of traditional dissemination mechanisms for research on new communication media. Working through traditional channels, it will likely be several more years before there is a strong body of published research on the implications of business use of the Internet.

Businesses will not wait for academics to carry out research on the effects of using the Internet. Organizations are already using the Internet and finding out for themselves some of the implications involved. What then can the academic world offer these Internet users today? Although new communication technologies are different in many ways from those they are replacing (see Middleton, 1997, for expansion of this argument), there are lessons to be learned from previous research ${ }^{5}$.

The Internet may not be considered a prime target for theoretical work, given its practical applications and constantly changing nature, but there is value in approaching the subject theoretically. Huber (1989) notes, "as the uses, capabilities, and forms of communication and decision-aiding technologies increase in their range, researchers must reassess what is

\footnotetext{
${ }^{4}$ http://hsb.baylor.edu/ramsower/acis/general.htm

${ }^{5}$ This paper focuses on new communication technologies used when carrying out business on the Internet. Many of the issues businesses face in using the Internet for communication with customers and suppliers external to the organization are expected to be similar to those it would face if using similar communication networks within the organization (e.g. intranets). While some of the conclusions drawn here will be applicable to both Internet and intranet technologies, the focus of this paper is on Internet technologies alone.
} 
known about the effects of these technologies because what is known may change." (p. 47) "New media impacts may condition or falsify hypothesized relationships developed by past research" (Williams \& Rice, 1983: 208), thus this paper will review that research with a view to understanding how it may apply to doing business on the Internet. The paper will conclude by identifying limits in our theoretical knowledge, and outlining potential future research projects.

\section{WHAT CAN WE LEARN FROM THEORY?}

Information systems literature covers a wide range of topics, including human-computer interaction, information systems development and implementation, decision support systems, the impact of computing on organizations, end-user computing, information technology diffusion, systems architectures and user involvement. (See Ives, Hamilton \& Davis, 1980; Culnan, 1986 and Swanson \& Ramiller, 1993 for overviews of the MIS literature.) Although not all the existing literature is of use in considering how businesses might develop and implement Internet technologies ${ }^{6}$, or in considering the implications of their rapid adoption by the business world, there are portions of the literature which may prove quite instructive and informative. In this paper, research on factors driving technological innovation, on technology adoption and critical mass, and on implementation will be considered, as these are likely to be most relevant in this context.

Organization theorists have studied the use of technology in organizations for many years. A key issue is the relationship between technology and

\footnotetext{
${ }^{6}$ See Middleton (1996) for a full description of Internet technologies as they currently exist.
} 
organizational structure, which has been scrutinized intensively with inconclusive results (see Barley, 1986; Barley, 1990; Burkhardt \& Brass, 1990; Comstock \& Scott, 1977; Hage \& Aiken, 1969; Hulin \& Roznowski, 1985; Orlikowski \& Robey, 1991; Stanfield, 1976; Thompson \& Bates, 1957; Trist \& Bamforth, 1951; and Woodward, 1965 for discussions of this relationship). It is often suggested however, that new communication technologies will have an impact upon organizational structure (Culnan \& Markus, 1987; Fulk \& DeSanctis, 1995; Markus, 1994; Nass \& Mason, 1990). This paper will review the research linking organizational structure and technology, and discuss how this research may be relevant to businesses adopting Internet technologies.

\section{What Are The Driving Forces Behind the Move To Doing Business on the Internet?}

To begin, it will be instructive to consider the forces pushing businesses onto the information highway so quickly. One of the reasons so many businesses are setting up shop on the web is that their competitors are already there. But the real objective of their business presence on the web is less clear. Many business sites are of little value to consumers, offering static information (known as "cobweb sites"), large and slow loading graphics, multiple "under construction" signs, and empty promises of more information coming soon. The web can be a potent tool to reach customers, to provide up to date product information, and to market goods and services (Gattiker, Janz \& Schollmeyer, 1996), but for most businesses, it appears that a presence on the web is more of a corporate vanity plate $(E n g, 1995)$ than part of a well-thought out strategic plan. In fact, a C/O survey indicated that

"while most respondents are prepared to accept the Internet as an extension of their companies' electronic communications tools, they are having trouble envisioning killer applications that the NII [National Information Infrastructure] might eventually spawn" (Buchanan, 1994). 
But despite not knowing what the real benefits of a web site are for their businesses, the "me-too-ism" continues. Trade publications, vendors and consultants urge businesses to get onto the web immediately, with one columnist advising that "the question isn't do you need a web site, but how soon can you get one?" (Currid, 1995). A cynic would note that those currently profiting most from the Internet are software and hardware vendors, and companies that sell advertising on their web pages (Wilder, 1996b).

Although businesses are unsure about why they are adopting new technologies, general issues of new technology adoption have been addressed by researchers. Huff and Munro's (1985) technology driven model, and Kling's (1980) systems rationalist perspective offer some insights as to why businesses are using the Internet in such numbers ${ }^{7}$. Cohen, March and Olsen's (1972) garbage can model and Feldman and March's (1981) work on symbolic uses of information also help explain the phenomenon.

Whether business use of the Internet and the World Wide Web will ultimately be effective or not, one thing is now clear. It is extremely difficult to determine precisely what functions the Internet and the World Wide Web best serve. They offer wonderful opportunities to expand communications between businesses and customers, but beyond that, in the words of computer company owner Bill Towler, "the Internet is a solution looking for a problem" (Nulty, 1995). In fact, it could be current business activities on the Internet that Cohen, March and Olsen (1972) are describing with their garbage can model of problem solving. Their description of organized anarchy applies to the Internet, characterized as it is by unclear technology and fluid participation. But is simply

\footnotetext{
${ }^{7}$ Verity \& Hof (1995) note that the Internet population doubles every 53 days, and that " $90 \%$ of companies with a portfolio of $\$ 350$ million and over are making the web a strategic component of their products and services".
} 
identifying business activities on the Internet as an example of a garbage can model of decision making of any value to the businesses involved? The garbage can model is more descriptive than prescriptive, yet it does indicate to businesses that they are not involved in a rational decision making process. This fact alone may be of some help to those businesses hesitating to join the rush onto the Internet. The realization that the Internet is a solution looking for a problem will help some businesses to understand that it is not the appropriate solution for problems that they might have, allowing them to leave their competitors to "play in the garbage can" (Hardy, Langley, Mintzberg and Rose, 1984), and freeing them to move on to more important business activities.

Integrating an Internet presence into a business can be an exercise in image management instead of an exercise in rational information seeking, improving customer service or matching product characteristics to the medium used to display these products. The business press encourages this activity, with Churbuck (1994), for example, suggesting that e-mail addresses alone are passé, and that being cool requires a home page. Scotland (1995) describes the desire to be on the Internet as the hip factor, quoting KPMG's Gordon Braun-Woodbury, who explains his company's web presence this way:

"We thought, let's get into it in a big way at the beginning so we're clearly there. Maybe a little ahead of our clients and maybe a little ahead of the marketplace in general. But we wanted to be there because we saw that's the way the future is moving." (p. C13)

This viewpoint reinforces the validity of the garbage can model as a descriptor of business Internet activities to date. But it also highlights the symbolic value that is accruing to the Internet, and is consistent with the observations made by Feldman \& March (1981) in another context, suggesting that information gathering for decision making purposes can serve a symbolic purpose. Organizations often gather far more information than they rationally 
require to make a decision, using excess information gathering tactics as symbols of competence and efficacy. Establishing a web presence is different than gathering information for decision making alone, but the symbolic nature of such an activity should not be underestimated. Businesses must not forget this point.

Although the Internet does fit into the garbage can model, and there are symbolic reasons for businesses establishing a presence on the web, there are also rational reasons for such actions. The technologies that enable the new forms of communication found on the World Wide Web do offer businesses significant advantages over non-networked communication mechanisms, including increased transmission speed and capacity, asynchronous communication and the elimination of geographic barriers (Middleton, 1997). It could be argued then, following Huff and Munro (1985), that the force driving businesses toward the Internet is a technological one.

In the technology driven model they describe, corporate planning takes a back seat to technological opportunism. Decisions are based on the capabilities of the technology under consideration, rather than on organizational needs. This approach differs somewhat from the garbage can approach, in that there is a decision making focus for the organization. For a technology driven model to succeed in assessing and adopting information technologies, Huff and Munro suggest there are two critical requirements. Firstly, organizations need to have a thorough understanding of the nature of the technology they are planning to implement, and of the implications of that implementation. Secondly, it is necessary for the technologists who are likely to be driving the decision processes to ensure that senior managers across the organization are supportive of the new technological initiatives being proposed. 
Thus, if it is technology that is driving an organization's move onto the Internet, the technologists implementing the systems must have a clear vision of the implications of doing business on the Internet. But as the technologists are likely to be systems programmers and developers, not specialists in marketing, communications or other functional areas, their understanding of the overall effects of establishing a web site, for example, may be limited. Therefore, organizations moving toward the Internet because of its technological promise must ensure that technical developers work with experts in the functional areas in which the technology will be deployed. Senior management support should be given to the formation of cross-functional teams to implement the new technologies.

Kling (1980) offers an alternative to Huff and Munro's (1985) technology driven perspective. His comprehensive review of empirical studies of computing in organizations identifies two broad perspectives on technology, systems rationalism and segmented institutionalism. Broadly speaking, the systems rationalist perspective describes situations in which technology is viewed as an instrument used in an organizational setting. The technology is deployed to meet organizational needs, and users come to accept the technology by participating in the design processes. When used well, the technology helps organizations to meet their goals more effectively and efficiently. It also promotes organizational adaptation to the environment, and job satisfaction for organizational members. Business use of the Internet has already been characterized as more symbolic, unpredictable and aimless than rational. But for businesses with a clear vision of their corporate strategies a rational approach to understanding technology deployment (as described by Huff \& Munro [1985] and Kling [1980]) is appealing. 
Although there is a strong case to be made that new technologies may be alienating, deskilling and that they may shape the environment and the actions of individuals within it (Kling's [1980] segmented institutionalist perspective, see for example Zuboff, 1988; Sale, 1995), this is not the vision that most organizations conjure up when considering their activities on the Internet. Instead, the rational perspective prevails, meaning that those responsible for implementing new technologies should be aware of Kling's observations on the systems rationalist approach. Two points are important here: i) the social features of an organization can have a strong influence on organizational adoption of computing, implying that adoption patterns will not be the same across organizations or within industries, and ii) the private rationales and concerns of computing personnel within organizations may have an impact upon the decisions made when adopting new technologies. Thus organizations should be aware that more than one technology strategy may be necessary to accommodate differences within and beyond their organizations. They must also ensure that technologies selected for use will support proposed business strategies and meet organizational needs, rather than just satisfying the technologists' desires.

This section has considered four explanations as to why businesses are eager to adopt Internet technologies: i) the garbage can approach; ii) symbolism/impression management; iii) the technology driven model and iv) the systems rationalist approach. Each approach has offered different insights, which are summarized in Table 1 below. 
Table 1: Forces Driving Businesses Onto The Internet

\begin{tabular}{|c|c|c|}
\hline Approach & Implications & Recommendations \\
\hline $\begin{array}{l}\text { Garbage Can } \\
\text { (Cohen, March \& Olsen, 1972) }\end{array}$ & $\begin{array}{l}\text { the business uses of the } \\
\text { Internet are not clear } \\
\text { as a solution looking for a } \\
\text { problem, the Internet is not } \\
\text { an appropriate venue for all } \\
\text { organizations }\end{array}$ & $\begin{array}{l}\text { identify concrete reasons } \\
\text { for establishing an Internet } \\
\text { presence, or adopt the } \\
\text { ambiguities into a business } \\
\text { plan }\end{array}$ \\
\hline $\begin{array}{l}\text { Symbolic } \\
\text { (Feldman \& March, 1981) }\end{array}$ & $\begin{array}{l}\text { - many businesses are } \\
\text { currently only on the web } \\
\text { for symbolic reasons }\end{array}$ & $\begin{array}{l}\text { - understand the reasons for } \\
\text { establishing an Internet } \\
\text { presence before doing so }\end{array}$ \\
\hline $\begin{array}{l}\text { Technology Driven } \\
\text { (Huff \& Munro, 1985) }\end{array}$ & $\begin{array}{l}\text { recognition of the technical } \\
\text { capabilities of the Internet } \\
\text { may encourage } \\
\text { organizations to adopt new } \\
\text { technologies for technical } \\
\text { reasons alone }\end{array}$ & $\begin{array}{l}\text { form integrated teams with } \\
\text { technical and functional } \\
\text { area members to meet the } \\
\text { Internet needs of both } \\
\text { groups }\end{array}$ \\
\hline $\begin{array}{l}\text { Systems Rationalist } \\
\text { (Kling, 1980) }\end{array}$ & $\begin{array}{l}\text { - technology will be used to } \\
\text { meet organizational goals } \\
\text { - the beliefs of technologists } \\
\text { within the organization may } \\
\text { influence technical } \\
\text { decisions }\end{array}$ & $\begin{array}{l}\text { - understand organizational } \\
\text { goals before implementing } \\
\text { new technologies } \\
\text { - base technical decisions on } \\
\text { organizational needs }\end{array}$ \\
\hline
\end{tabular}

\section{What Insights Does the Literature Offer About Adoption of New Technologies?}

The garbage can, symbolic, technology driven and systems rationalist approaches to technological innovation offer some insights as to the forces that motivate innovation within organizations. But for a communication innovation to be truly successful, it must be widely used and accepted. This section of the paper will consider critical mass theory (Markus, 1990), concurrent deployment of new and old technologies, adoption of technological innovation theory (Attewell, 1992; Rogers, 1983) and users' perceptions of new technologies (Davis, 1989; Davis, 1993), in order to better understand the factors related to widespread adoption and acceptance of the new communication technologies embodied in the Internet. 
Markus' work on critical mass theory offers insights as to how an interactive communication mechanism may achieve universal access, that is "the ability of any member of the community to reach all other members through the medium" (1990: 194). While this may not be achievable in the short term, the longer term success of Internet use by businesses will be reliant upon universal or near universal access to the medium (Bell \& Gemmell, 1996). To achieve universal access, four conditions must be met: i) appropriate infrastructure must be in place, ii) community members must have access devices to use the new medium, iii) users must have the knowledge and skills needed to use the medium, and iv) users must exercise "communication discipline". For example, users must check their e-mail service regularly, whether they are sending messages or not, and they must respond to messages they receive in a timely manner. Without this communication discipline, the medium might be accessible by all community members, but not fully utilized, and thus it would be ineffective.

Universal access is not likely to be achieved overnight, but Markus (1990) offers some suggestions as to how to facilitate adoption of a new technology by a critical mass of users. These recommendations can be used to encourage adoption of new technologies within an organization. More importantly, for businesses wishing to use a new communication technology as part of a business strategy, these suggestions can encourage technological adoption within an entire business community. One tactic is to mandate use of the technology within the target community, although this may lead to some resistance. An alternative strategy is to select initial users of the technology carefully (e.g. regular customers), trying to choose those who will actively champion the new technology and act as role models for other community members. For example, those who tend to use the technology for originating 
communication, rather than just for gathering information, are most likely to be early adopters. Positive inducements can be given to those who adopt the innovation. One issue that must be addressed when trying to achieve a critical mass of users is technological standards. Businesses must make the decision whether to cater to the lowest common technology denominator among users (e.g. assuming all users will be able to access the Internet with a 14.4 Kbps modem) or to use more sophisticated technology. Businesses who do not cater to the lowest common technological denominator will either have to exclude a portion of their target audience because they do not have the sophisticated technology required to access Internet sites, or ensure that all members in the target group are provided with suitably sophisticated technology.

As Markus (1990) observes, a consequence of not achieving universal access is that old technologies must be supported simultaneously with the new ones that are designed to replace the old, an inefficient situation. Before universal access is achieved or even sought then, there are some questions that must be addressed. Will universal access to a new technology mean that services previously available will be discontinued? For example, if a firm decides to provide product information on the web, will it discontinue production of a printed product catalogue? If new and old technologies and services are maintained, will adequate user support be provided for both, or will users be expected to migrate from the old to the new with limited support? How long will old technology co-exist with the new, or is this a factor beyond the control of those introducing the new technology? Markus (1990), Culnan \& Markus (1987) and March and Sproull (1990) consider these issues. Are there hidden functionalities of the old technology that may not be replicated by the new (Sproull \& Kiesler, 1991)? Does a competency trap (March \& Sproull, 
1990) exist, meaning that as competency on older technologies improves, users are less likely to migrate to new, improved technologies, or if they do shift, they are less competent with the new technology, and thus suffer productivity decreases? For businesses planning to establish a presence on the Internet these are important issues. Businesses must understand how their customers (i.e. the users mentioned above) will respond to the introduction of new technologies.

Research indicates that large firms have a tendency to adopt innovations before smaller ones (Attewell, 1992), and that small businesses adopt new technologies in different ways than large businesses (Cragg \& King, 1993; Massey, 1986). This may not be the case with adoption of the Internet, as the technology is relatively cheap and it is easy to establish an Internet presence. The important point here however is to consider the characteristics of the target audience for an organization's Internet activities. If the target audience or market is slow to adopt new technologies, an Internet presence is not likely to be an effective business tool ${ }^{8}$.

Rogers' (1983) gravity model suggests that the speed with which an innovation is adopted is related to the size of the population in which it is introduced. According to this model, in the U.S. new technologies will appear earliest in Southern California, and in the Northeast region (between Boston and Washington), as has been the case with the establishment of Internet

\footnotetext{
${ }^{8}$ Surveys of Internet user demographics are useful for businesses trying to determine whether an Internet presence would help them reach a specific target group. Two such surveys can be found at: http://www/cc/gatech.edu/gvu/user_surveys/survey-04-1995/ and http://future.sri.com.
} 
domains $^{9}$. Therefore, businesses wishing to test market their World Wide Web sites, or to implement Internet access on a regional basis can select test markets based on population, with a reasonable understanding of the technological penetration expected in that market.

One final factor related to the adoption of new technologies is the user's perception of the technology. Individual user characteristics are important in understanding whether a technology will be adopted or not. Businesses that recognize factors likely to encourage use of a given technology are more apt to succeed in using it. Davis and his colleagues (Davis, 1989; 1993; Davis, Bagozzi \& Warshaw, 1989) have conducted extensive research into user acceptance of computing technology, concluding that perceived usefulness is more influential than ease of use in determining intended usage of a new computer technology. They also note that actual computer use can be predicted reasonably accurately from intended use, thus it is suggested that a perception of usefulness must be instilled in users if they are to adopt a new computer technology. For businesses contemplating a presence on the Internet then, it is important that their activities be well thought out, and offer value to their customers that could not be obtained elsewhere. Concerns about ease of access to the Internet are less important than establishing perceived value for Internet services.

The literature on technological adoption offers many insights for businesses intending to offer goods and services over the Internet. Businesses must work to encourage universal access to the Internet, but must also consider how they will make the transition from non-Internet supported

\footnotetext{
${ }^{9}$ As of May $1995,17 \%$ of the more than 28,000 registered Internet domains in the U.S. were in California, $23.5 \%$ were in the North East. Source: http://nic.merit.edu /nsfnet/statistics/nets.by.state
} 
services to Internet supported ones, and at what point this transition will take place. Table 2 summarizes the technology adoption issues discussed in this section.

Table 2: Theories of Technology Adoption

\begin{tabular}{|c|c|c|}
\hline Approach & Implications & Recommendations \\
\hline $\begin{array}{l}\text { Critical Mass Theory } \\
\text { (Markus, 1990) }\end{array}$ & $\begin{array}{l}4 \text { factors for universal access: } \\
\text { - appropriate infrastructure } \\
\text { - access devices for new } \\
\text { medium } \\
\text { - user training } \\
\text { - users must exercise } \\
\text { "communication discipline" }\end{array}$ & $\begin{array}{l}\text { Implementation Tactics: } \\
\text { - mandate use of new } \\
\text { technology } \\
\text { - select champions as role } \\
\text { models } \\
\text { - ensure appropriate } \\
\text { technological standards are } \\
\text { in place } \\
\end{array}$ \\
\hline $\begin{array}{l}\text { Concurrent Deployment } \\
\text { (Culnan \& Markus, 1987; } \\
\text { March \& Sproull, 1990; Sproull } \\
\text { \& Kiesler, 1991) }\end{array}$ & $\begin{array}{l}\text { - how long will old } \\
\text { technologies be supported } \\
\text { once new ones are } \\
\text { available? } \\
\text { - competency traps in old } \\
\text { technologies? } \\
\text { - hidden functionalities in old } \\
\text { technologies? }\end{array}$ & $\begin{array}{l}\text { - plan phase out of old } \\
\text { technologies and migration } \\
\text { to new } \\
\text { - work with users to } \\
\text { understand all functionality } \\
\text { of old technologies before } \\
\text { implementing new ones }\end{array}$ \\
\hline $\begin{array}{l}\text { Adoption of Technological } \\
\text { Innovations } \\
\text { (Attewell, 1992; Rogers, } \\
\text { 1983) }\end{array}$ & 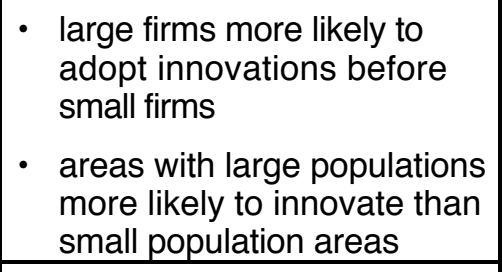 & $\begin{array}{l}\text { - target business activities to } \\
\text { early adopters } \\
\text { - select test markets based } \\
\text { on population size }\end{array}$ \\
\hline $\begin{array}{l}\text { Users Perceptions of } \\
\text { Technology } \\
\text { (Davis, } 1989 ; 1 \text { 1993; Davis, } \\
\text { Bagozzi \& Warshaw, 1989) }\end{array}$ & $\begin{array}{l}\text { users must perceive that } \\
\text { new technologies are } \\
\text { useful in order to adopt } \\
\text { them }\end{array}$ & $\begin{array}{l}\text { focus attention on creating } \\
\text { value in Internet services, in } \\
\text { addition to making access } \\
\text { simple }\end{array}$ \\
\hline
\end{tabular}

\section{Implementation Issues}

The preceding section discussed literature on the adoption of new technologies. This section will consider the literature on implementation. The two literatures are similar, but the focus of the implementation literature is on organizational attempts to encourage the adoption of new technologies, as opposed to broad macro strategies for diffusion of innovation. Zmud (1984) acknowledges this distinction, noting that recognition and assessment of 
information technology innovations is a separate activity to facilitating the diffusion of such innovations into individual organizations. Kwon \& Zmud (1987) define IS implementation as "an organizational effort to diffuse an appropriate information technology within a user community" (p. 231).

Markus \& Robey (1983) stress the need for information systems to fit their organizational contexts. Effective systems implementation will be encouraged if there is a fit between the information system and i) the users' motivations for employing the system, ii) the organization's structural dimensions and iii) the power distributions within the organization. An appropriate organizationenvironment interface is necessary as well. Kwon \& Zmud (1987) also offer a contextual perspective on IS implementation, noting the importance of understanding users, the organization, the task to which the new technology will be applied, the nature of the technology itself, and the environment in which it is being introduced. Eveland and Tornatzky (1990) echo this concern for understanding organizational context when attempting to implement a new technology. In their view, in order to achieve success in implementation the following factors must be considered: i) the nature of the technology to be implemented, ii) the characteristics of the users, iii) the characteristics of the deployer of the technology, iv) the boundaries within or between the deployers and the users and $v$ ) the characteristics of the communications and transactions mechanisms. Successful implementation requires the support of top management, high quality design of the system being implemented, interaction between the designers and users in the design and implementation stages, and motivated, capable users (Kwon \& Zmud, 1987).

What does this mean for organizations undertaking business activities on the Internet? They must fully understand the strengths and weaknesses of the 
media they choose, and target their activities to the appropriate people within each media sector. Not all users will be interested in all services that are offered, thus careful matching between perceived user needs and business offerings must take place. However, one of the strengths of the Internet is the flexible means by which information can be stored and retrieved. With good design, web sites can be established to target multiple audiences. Hypertext links allow users to select the level of detail they require, thus meaning that a simple web interface can provide adequate information either to a prospective customer merely seeking a product catalogue, or to an existing customer requiring detailed specifications on a particular product.

By offering services through e-mail, mailing lists, web interfaces or some combination thereof, organizations should be able to achieve a good fit between user needs, available technology, and existing organizational structures, as mandated by the implementation literature. Intelligent design of Internet interfaces is the primary success factor ${ }^{10}$. If the Internet presence is well-designed, it will be user friendly and easily accessible to all potential users. Boundaries between organizations and their clients will be transparent, regardless of the nature of the interface selected.

Implementation research highlights the need for a strong understanding of the technological capacities of the Internet and the expectations of the users, and an ability to match the two. Table 3 summarizes this research.

\footnotetext{
${ }^{10} \mathrm{Because}$ it is easy to code text and graphics for use in web pages, there are many individuals and corporations offering web page creation services. Businesses should choose their designers carefully, making sure that the designers understand the purposes of the web site and the technologies available to anticipated users. Sarna \& Febish (1996), Weinman (1996) and McCanna (1996) offer some tips for web page design.
} 
Table 3: Implementation of New Technologies

\begin{tabular}{|c|c|c|}
\hline Approach & Implications & Recommendations \\
\hline $\begin{array}{l}\text { Organizational Validity } \\
\text { Markus \& Robey (1983) }\end{array}$ & $\begin{array}{l}\text { - new information systems } \\
\text { must fit their organizational } \\
\text { contexts }\end{array}$ & $\begin{array}{l}\text { - understand organization } \\
\text { and technology before } \\
\text { implementation }\end{array}$ \\
\hline $\begin{array}{l}\text { Contextual Perspective } \\
\text { Kwon \& Zmud (1987) }\end{array}$ & $\begin{array}{l}\text { - understand users needs, } \\
\text { organization context and } \\
\text { environment } \\
\text { - match tasks to technologies }\end{array}$ & $\begin{array}{l}\text { - involve users in design and } \\
\text { implementation }\end{array}$ \\
\hline $\begin{array}{l}\text { Organizational Context } \\
\text { Eveland \& Tornatzky (1990) }\end{array}$ & $\begin{array}{l}\text { understand characteristics } \\
\text { of users and deployers of } \\
\text { technology } \\
\text { - understand boundaries } \\
\text { between deployers and } \\
\text { users }\end{array}$ & $\begin{array}{l}\text { target specific Internet } \\
\text { activities to particular user } \\
\text { groups }\end{array}$ \\
\hline
\end{tabular}

\section{Theories of Media Choice}

The prescriptions for fit between user needs and communication technologies are consistent with and analogous to the principles of media richness theory (Daft \& Lengel, 1986; Daft, Lengel \& Trevino, 1987), which suggest that businesses must take care to match their choice of communication media to the nature of the messages being delivered. It is fit between an individual message and its delivery medium that is considered to be important, rather than a match between the message and the organizational context as a whole. For example, Daft and Lengel's (1986) model of information processing suggests that less rich media such as e-mail be used for basic information exchange, rather than for complex interactions.

However, the basic premises of media richness theory are being questioned (see Lee, 1994 for a review of recent research on the subject), and categorization of media in terms of their richness has become more difficult. New communication technologies are bringing together lean and rich media 
(e.g. videoconferencing with document sharing approximates face-to-face communication [Kydd \& Ferry, 1994]), making generalizations about lean and rich media less useful. D'Ambra and Rice (1994) have found voice mail to be equally rich as face-to-face conversation, although the telephone alone is considered less rich.

Media richness theory predicts that richer media will be used for more equivocal situations. However, recent research (Rice, More \& D'Ambra, 1995) indicates that some new technologies such as e-mail will be widely used in situations with varying levels of equivocality. They suggest that exposure to email encourages its use across situations. While it is not clear that frequent email users consider it a richer medium than infrequent users, the use of e-mail in both equivocal and non-equivocal situations indicates that media richness theory does not always predict media choice when using new communication technologies. This is confirmed by Lee (1994), who found that it was not the email medium itself that was rich or lean, it was the interaction between the medium and the organizational context that determined richness, contradicting media richness theory.

Is the prescriptive media richness model appropriate when considering use of Internet technologies? Although there is no longer agreement on which media can be categorized as rich or lean, there is value in understanding the characteristics of a medium and matching them to the communication objective. Businesses should take care then, to match the nature of the information they intend to disseminate to the characteristics of the technology being used. As the World Wide Web can support information dissemination in video, audio and text formats, it would be more appropriate for delivery of complex information and materials, than would e-mail alone, for example. 
Given the flexibility of Internet interfaces, it is expected that the Internet could be used effectively in both equivocal and non-equivocal situations, but businesses must match specific Internet technologies to business communication needs.

\section{Technology and Structure Research ${ }^{11}$}

Recent publications have given much attention to the technology-structure relationship, with the underlying assumption being that new technologies are changing organizational structure, for example by flattening hierarchical structure, and moving control of decision-making downwards within the organization (Culnan \& Markus, 1987; Fulk \& DeSanctis, 1995; Markus, 1994; Morgan, 1988; Nass \& Mason, 1990; Stewart, 1994; Tapscott \& Caston, 1993; Thach \& Woodman, 1994). An understanding of this relationship provides a base for understanding how technology impacts organizations as a whole, not just their structures.

The relationships between technology and structure have been studied extensively (Fry, 1982; Gerwin, 1981; Hickson, Pugh \& Pheysey, 1969; Scott, 1990; Trist \& Bamforth, 1951; Woodward, 1958, 1965). In addition, numerous works examine structure and its relationship specifically to information technology (Barley, 1990a; Burkhardt \& Brass, 1990; Burn, 1989; Carter, 1984; Jones, 1990; Markus \& Robey, 1988; Orlikowski, 1992; Orlikowski \& Robey, 1991; Pfeffer \& Leblebici, 1977; Robey, 1977; Robey, 1981; Zeffane, 1989). Despite the volume of research, there is no overall consensus as to the nature of the relationship between adoption of technology and organizational structure, although there is empirical evidence to support the existence of a relationship (Attewell \& Rule, 1984; Fry, 1982; Robey, 1995). As Scott (1990: 109) notes:

\footnotetext{
${ }^{11} \mathrm{Parts}$ of this section are adapted from Middleton (1995).
} 
the relationship between technology and organizations may be characterized as a two-edged sword. Thrusting in one direction reveals the impact of a given technology on organizational structure and performance. The counterthrust emphasizes that organizational structures vary in their capacity to appropriate or to generate new technologies.

Thus, in some instances technology is considered to be the determinant of structure (the technological imperative), while in others structure is found to determine technological choice (the organizational imperative) ${ }^{12}$. Recently a third possibility has emerged in the form of the structuration approach (Giddens, 1984), in which technology is shaped by structure and structure is simultaneously shaped by technology.

This paper will not review the literature on these 3 perspectives ${ }^{13}$. But it is important for businesses to understand that the adoption of new technologies may have some impact upon internal organizational structure (the technological imperative). For example, it is suggested that adoption of e-mail may lead to flatter organizations, with fewer layers of management and less hierarchy. Although this anticipated delayering will not happen overnight, it may have an impact on human resource planning for the medium to long term. It is also noted that the introduction of new technologies will have an impact upon communications patterns, both within an organization and between its customers and employees. Jobs may need to be redesigned to cope with changing communication mechanisms (e.g. the primary means of providing customer service might switch from telephone support to e-mail support, meaning that customer service representatives would likely do their jobs in new ways).

\footnotetext{
${ }^{12} A$ population ecology perspective on organizations (Hannan \& Freeman, 1977) would suggest that structure is determined by a natural selection process, and thus technology is irrelevant, but this perspective will not be discussed here.

${ }^{13}$ See Middleton (1995) for a complete review of the technology-structure literature.
} 
The organizational imperative anticipates that organizational structure will dictate, or at least influence how technologies are adopted. Drawing parallels with the IS research on implementation then, it is noted that Internet activities must be developed with a clear understanding of the context of the organization supporting these activities. An Internet strategy developed for a large hierarchical organization will not likely be a success for a small dynamic operation. This point should be kept in mind when hiring external consultants to develop corporate Internet sites.

Most organizations will identify with a structuration approach when using Internet technologies. As Internet sites are virtual rather than physical, they are easily modified, changed and redesigned without significant production costs. (Developers must be paid, but the costs associated with producing a physical product [e.g. printing and distribution] are eliminated in this environment.) Organizations must expect that Internet development will be an iterative process, and take continual advantage of the opportunities to adjust structure to technology and vice versa.

So what can businesses conclude from investigations of technology and organizational structure? The management press e.g. (Morgan, 1988; Stewart, 1994; Thach, 1994) views new technology as a strong determinant of organizational structure, consistent with the technological imperative perspective. But the academic literature on technology and structure indicates that there are alternative perspectives which may better describe the technology-structure interaction. In reality, businesses should be prepared for all of the potential interactions just discussed. The implications of each perspective of technology-structure interaction are summarized in Table 4. 
Table 4: Technology-Structure Interactions

\begin{tabular}{|c|c|c|}
\hline Approach & Implications & Recommendations \\
\hline Technological Imperative & $\begin{array}{l}\text { - adopting new technologies } \\
\text { will influence organizational } \\
\text { structure }\end{array}$ & $\begin{array}{l}\text { - consider potential changes } \\
\text { in organizational structure } \\
\text { when making human } \\
\text { resource plans } \\
\text { - expect that jobs of workers } \\
\text { using new technologies will } \\
\text { require some redesign }\end{array}$ \\
\hline Organizational Imperative & $\begin{array}{l}\text { the context of the business } \\
\text { (e.g. structure) will have an } \\
\text { impact upon the way new } \\
\text { technologies are adopted }\end{array}$ & $\begin{array}{l}\text { - technology implementation } \\
\text { plans must be developed } \\
\text { for specific organizational } \\
\text { settings } \\
\text { - understand that } \\
\text { consultants who develop } \\
\text { Internet strategies for large } \\
\text { corporations may not be } \\
\text { equally good at developing } \\
\text { strategies for smaller } \\
\text { organizations } \\
\end{array}$ \\
\hline Structuration & $\begin{array}{l}\text { the introduction of new } \\
\text { technologies will change } \\
\text { organizational structure } \\
\text { - changes in organizational } \\
\text { structure will lead to } \\
\text { changes in the way new } \\
\text { technologies are used }\end{array}$ & $\begin{array}{l}\text { - be prepared for many } \\
\text { iterations when developing } \\
\text { an Internet presence } \\
\text { - be adaptive }\end{array}$ \\
\hline
\end{tabular}

\section{LESSONS FROM THE LITERATURE}

The preceding sections have reviewed the IS literature on technology innovation and adoption, implementation and media choice. The conclusions drawn offer many insights for organizations considering doing business on the web. The key lessons are as follows:

1. Recognize that the Internet does not offer a solution to all problems. The Internet may not provide the best communication options for a given organization. Organizations must understand why they are planning to be on the Internet, even if the reason is symbolic alone. It is acceptable (and indeed recommended in many instances) for businesses to continue operating without using the Internet. 
2. Understand the technology before planning to implement it. Ensure that both organizational and technological needs are being met in any proposal to adopt Internet technologies. Base technological decisions on organizational requirements, which must be clearly identified.

3. Understand the importance of universal access to the Internet, and how it can be facilitated.

4. Target activities to early adopters, taking care to focus efforts on providing useful services. Plan for new technologies to supplant old ones in an orderly manner.

5. Involve customers and other technology users in design and implementation of Internet services. Understand user needs, so that specific activities can be targeted for given groups.

6. Understand the characteristics of the individual Internet technologies. Match media characteristics to business tasks.

7. Anticipate changes in organizational structure as communication patterns change. Be prepared to redesign jobs as necessary, and expect Internet development to be an iterative process.

\section{OPPORTUNITIES FOR FUTURE RESEARCH}

How valid are lessons based on existing research if the Internet and related technologies are substantially different from some existing communication technologies and information systems? What limitations or caveats need to be considered in conjunction with the lessons just outlined? There are 4 main areas of concern that must be recognized. These areas are discussed below, along with some research ideas that could address these concerns. 
1. Although the impacts of using the Internet may be huge, the initial investment (small), ease of use (high), and the nature of the innovation make it different from other technological innovations. A web page can be created in 10 minutes with a word processor, thus design issues are substantially different from those for complex software or information systems. With minimal training, anyone can create a web page, unlike a decision support system, for example. Connecting to the Internet requires free software, a modem and a telephone, all of which are easily accessible. Thus, more research on Internet innovations is needed to determine whether traditional innovation patterns will apply.

This research could draw upon Roger's (1983) work on diffusion of innovations. It would need to have two separate branches, one investigating adoption of Internet technologies by businesses, and the other looking at consumer behaviour patterns. Some of this work has begun, with organizations like Statistics Canada including questions about Internet usage in their surveys of household facilities and equipment (Mitchell, 1996). But it is up to academics to interpret this data and to determine research agendas. For example, just because individuals have access to the Internet does not mean that they use it regularly, or that they use it to access business sites. Furthermore, each individuals' usage patterns are likely to be different, and there will be differences in behaviour between people accessing the Internet for business purposes (e.g. at work) and those using it for leisure (from home). Research should consider the importance of access to high bandwidth networks in determining usage patterns, something that can be investigated by interviewing and surveying participants in information highway trials (e.g. Newmarket's Intercom Ontario project). 
Researchers should work with businesses to determine how they are using the Internet. For example, is the Internet presence mainly symbolic (in which case it may be championed by senior executives, but not actually used frequently by customers and employees), or is it an integral part of a business' corporate strategy? Interviews with customers and employees will help researchers get at these issues, as will observation of how Internet sites, for example, are developed and promoted to their target users.

2. Innovation research generally focuses on how to get internal people to use a specific technology, not on how external users like customers might adopt the technology. In the case of businesses using the Internet, they have less influence over customer behaviour than employers have over their employees. For this reason then, it is not certain that the prescriptions from innovation research will be effective when encouraging external users to adopt new technologies. No doubt businesses will find ways to encourage new technology adoption by their customers. This is an area in which IS researchers should focus their attention.

Specifically, researchers should investigate user perceptions of the value they receive from using the Internet. By surveying and interviewing people in settings where technology is readily available for high speed Internet access, it will be possible to isolate issues related to ease of use from those related to perceived usefulness. This provides an opportunity to test Davis's theories $(1989,1993)$, and to determine whether the best means to coax users onto the Internet is to convince them of its intrinsic value.

3. Implementation research also focuses on internal participants. There is little research that considers how to design systems for external 
customers, focusing instead on internal organizational needs. While the basic design principles of consultation and understanding user needs still apply, putting them into practice is much more difficult when the individuals or organizations for whom the design is being carried out are external to the designing organization. Researchers need to identify mechanisms by which external users can be consulted, but this is difficult when one of the strengths of Internet communication is that it facilitates contact with individuals or organizations previously unknown to the initiating business. Fortunately, information highway trial sites offer access to groups of external users who can become part of the consultative process.

4. Organizational structure is a difficult construct to conceptualize and measure, as it doesn't refer to a discrete physical property (Middleton, 1995). While it is expected that structure will be changed in some ways by the adoption of Internet technologies, it may be hard to determine when organizational level structural changes have taken place. It is suggested then that research looking at the organizational impacts of introducing Internet technologies focus on individual level issues first. For example, it is reasonably easy to determine whether a job has been changed as a result of adopting technology (this can be done by interviewing the employee or someone who deals with the employee on a regular basis, either internal or external to the employee's organization). Longer term research can look at changes to organizational structure, but these may not be evident immediately upon adoption of new technologies.

An additional issue of interest to organizational researchers is whether the adoption of a new technology by one party in a buyer-supplier 
relationship will have an impact on the organizational structure of the other party. This is not something that has been addressed in the literature. It could be studied by identifying customers who deal with an organization that has adopted Internet technologies and tracking the customers' organizational responses when using the Internet to communicate with their supplier.

\section{CONCLUSIONS}

Communications, organizational and information systems research offers a number of important lessons for businesses contemplating the establishment of an Internet presence. However, as existing IS research has focused primarily on adoption and implementation of technologies significantly different to the networked communication technologies the Internet provides, there are some gaps in our understanding of how these new technologies will be adopted.

This paper identifies two challenges for information systems researchers. The first is to disseminate what we already know about technological innovation, and apply it specifically to the Internet. The second challenge is to undertake research projects aimed specifically at Internet technologies in order to fully understand the implications of their widespread adoption by businesses. 


\section{BIBLIOGRAPHY}

Attewell, P. (1992). "Technology Diffusion and Organizational Learning: The Case of Business Computing." Organization Science, 3 (1), 1-19.

Attewell, P., \& Rule, J. (1984). "Computing and Organizations: What We Know and What We Don't Know." Communications of the ACM, 27 (12), 1184-1191.

Barley, S. (1986). "Technology as an Occasion for Structuring: Evidence from Observation of CT Scanners and the Social Order of Radiology Departments." Administrative Science Quarterly, 31, 78-108.

Barley, S. (1990). "The Alignment of Technology and Structure through Roles and Networks." Administrative Science Quarterly, 35, 61-103.

Bell, G., \& Gemmell, J. (1996). "On-ramp Prospects for the Information Superhighway Dream." Communications of the ACM, 39 (7), 55-61.

Buchanan, L. (1994). "Getting Your Ducks Online”. CIO, 1 December, 28-29.

Burkhardt, M. E., \& Brass, D. J. (1990). "Changing Patterns or Patterns of Change: The Effects of a Change in Technology on Social Network Structure and Power." Administrative Science Quarterly, 35, 104-127.

Burn, J. M. (1989). "The Impact of Information Technology on Organisational Structures." Information \& Management, $16,1-10$.

Carter, N. M. (1984). "Computerization as a Predominate Technology: Its Influence on the Structure of Newspaper Organizations." Academy of Management Journal, 27 (2), 247$\underline{270 .}$

Churbuck, D. C. (1994). "Dial-a-catalog." Forbes, 10 October, 126-130.

Cohen, M. D., March, J. G., \& Olsen, J. P. (1972). "A Garbage Can Model of Organizational Choice." Administrative Science Quarterly, 17(1), 1-25.

Comstock, D. E., \& Scott, W. R. (1977). "Technology and the Structure of Subunits: Distinguishing Individual and Workgroup Effects." Administrative Science Quarterly, 22, 177-202.

Cortese, A. (1995). "Cyberspace”. Business Week, 27 February, 78-86.

Cragg, P., \& King, M. (1993). "Small-Firm Computing: Motivators and Inhibitors." Management Information Systems Quarterly, 17 (1), 47-60.

Culnan, M. J. (1986). "The Intellectual Development of Management Information Systems, 1972-1982: A Co-Citation Analysis." Management Science, 32(2), 156-172.

Culnan, M. J., \& Markus, M. L. (1987). "Information Technologies." In F. M. Jablin, L. L. Putnam, K. H. Roberts, \& L. W. Porter (Eds.), Handbook of Organizational Communication,. Newbury Park, CA: Sage.

Currid, C. (1995). "Head Out to the Highway". InformationWeek, 1 May, 142.

D’Ambra, J., \& Rice, R. E. (1994). "Multimethod Approaches for the Study of ComputerMediated Communication, Equivocality and Media Selection." IEEE Transactions of Professional Communication, 37(4), 231-239.

Daft, R. L., \& Lengel, R. H. (1986). "Organizational Information Requirements, Media Richness and Structural Design.” Management Science, 32, 554-571.

Daft, R. L., Lengel, R. H., \& Trevino, L. K. (1987). "Message Equivocality, Media Selection and Manager Performance: Implications for Information Systems." Management Information Systems Quarterly, 355-366. 
Davis, F. D. (1989). "Perceived Usefulness, Perceived Ease of Use, and User Acceptance of Information Technology." Management Information Systems Quarterly, 13(2), 319-340.

Davis, F. D. (1993). "User Acceptance of Information Technology: System Characteristics, User Perceptions and Behavioral Impacts." International Journal of Man-Machine Studies, 38, 1-13.

Davis, F. D., Bagozzi, R. P., \& Warshaw, P. R. (1989). "User Acceptance of Computer Technology: A Comparison of Two Theoretical Models." Management Science, 35(8), 982-1003.

Eng, P. M. (1995). "Big Business on the Net? Not Yet". Business Week, 26 June, 100-101.

Eveland, J. D., \& Tornatzky, L. (1990). "The Development of Technology." In L. Tornatzky \& M. Fleischer (Eds.), The Processes of Technological Innovation, (Chapter 6). Lexington, MA: Lexington Books. (as cited by Attewell, 1992)

Feldman, M. S., \& March, J. G. (1981). "Information in Organizations as Signal and Symbol." Administrative Science Quarterly, 26, 171-186.

Fry, L. W. (1982). "Technology-Structure Research: Three Critical Issues." Academy of Management Journal, 25 (3), 532-552.

Fulk, J., \& DeSanctis, G. (1995). "Electronic Communication and Changing Organizational Forms." Organization Science, 6 (4), 337-349.

Gattiker, U., Janz, L., \& Schollmeyer, M. (1996). "Internet Access: Managing Costs and Benefits." Business Quarterly (Autumn), 85-92.

Gerwin, D. (1981). "Relationships between structure and technology." In P. C. Nystrom \& W. $\mathrm{H}$. Starbuck (Eds.), Handbook of Organizational Design, (Vol. 2, pp. 3-38). New York, NY: Oxford University Press.

Giddens, A. (1984). The Constitution of Society. Berkeley, CA: University of California Press.

Hage, J., \& Aiken, M. (1969). "Routine Technology, Social Structure and Organizational Goals." Administrative Science Quarterly, 14, 366-376.

Hannan, M. T., \& Freeman, J. (1977). "The Population Ecology of Organizations." American Journal of Sociology, 82 (5), 929-964.

Hardy, C., Langley, A., Mintzberg, H., \& Rose, J. (1984). "Strategy Formulation in the University Setting." In J. L. Bess (Ed.), College and University Organization: Insights from the Behavioral Sciences, (pp. 169-210). New York, NY: New York University Press.

Hickson, D. J., Pugh, D. S., \& Pheysey, D. C. (1969). "Operations Technology and Organization Structure: An Empirical Reappraisal." Administrative Science Quarterly, 14, 378-397.

Huber, G. P. (1989). "A Theory of the Effects of Advanced Information Technologies on Organizational Design, Intelligence, and Decision Making." Academy of Management Review, 15(1), 47-71.

Huff, S., \& Munro, M. C. (1985). "Information Technology Assessment and Adoption: A Field Study." Management Information Systems Quarterly(December), 327-340.

Hulin, C. L., \& Roznowski, M. (1985). "Organizational Technologies: Effects on Organizations' Characteristics and Individuals' Responses." Research in Organizational Behavior, 7, 39-85.

Ives, B., Hamilton, S., \& Davis, G. B. (1980). "A Framework for Research in Computer-Based Management Information Systems." Management Science, 26(9), 220-232.

Jennings, C. G. (1996). "Creating an Internet Presence for Your Business - Part I." CGA Magazine (June), 34-39, 68.

Jones, M. R. (1990). "The Impact of Organisations on Computers." Research Paper 3/90, Cambridge University Engineering Department . 
Kling, R. (1980). "Social Analyses of Computing: Theoretical Perspectives in Recent Empirical Research." ACM Computing Surveys, 12(1), 61-110.

Kwon, T. H., \& Zmud, R. W. (1987). "Unifying the Fragmented Models of Information Systems Implementation.” In R. J. Boland \& R. A. Hirschheim (Eds.), Critical Issues in Information Systems Research, (pp. 227-252). Chichester, UK: John Wiley \& Sons, Ltd.

Kydd, C. T., \& Ferry, D. L. (1994). "Managerial Use of Video Conferencing." Information \& Management, 27(6), 369-375.

Lee, A. S. (1994). "Electronic Mail as a Medium for Rich Communication: An Empirical Investigation Using Hermeneutic Interpretation." Management Information Systems Quarterly, 18(2), 143-158.

March, J. G., \& Sproull, L. S. (1990). "Technology, Management and Competitive Advantage." In P. S. Goodman \& L. S. Sproull (Eds.), Technology and Organizations, (pp. 144-173). San Francisco, CA: Jossey-Bass.

Markus, M. L. (1990). “Toward a 'Critical Mass' Theory of Interactive Media.” In J. Fulk \& C. W. Steinfield (Eds.), Organizations and Communication Technology, (pp. 194-218). Newbury Park, CA: Sage.

Markus, M. L. (1994). "Electronic Mail as the Medium of Managerial Choice." Organization Science, 5 (4), 502-527.

Markus, M. L., \& Robey, D. (1983). "The Organizational Validity of Management Information Systems." Human Relations, 36(3), 203-226.

Markus, M. L., \& Robey, D. (1988). "Information Technology and Organizational Change: Causal Structure in Theory and Research." Management Science, 34 (5), 583-598.

Massey, T. K. (1986). "Computers in Small Business: A Case of Under-utilization." American Journal of Small Business, 11 (2), 51-60.

McCanna, L. (1996). Creating Great Web Graphics: MIS Press.

McKenney, J. L. (1988). "How Managerial Use of Electronic Mail Influences Organizational Information Processing: An Exploratory Study." Harvard Business School (Working Paper \#88-067).

Middleton, C. A. (1995). Do New Communication Technologies Have an Impact on Organizational Structure? A Research Design to Investigate the Technology-Structure Relationship, Using Quantitative and Qualitative Methods. Working Paper: York University.

Middleton, C. A. (1997). New Communication Networks: Understanding How Intranets and the Internet can be used by Organizations Working Paper 21-97: York University.

Mitchell, A. (1996). "Few succumbing to Internet's allure". The Globe and Mail, 24 October 1996, pp. A1, A21.

Morgan, G. (1988). Riding the Waves of Change. San Francisco: Jossey-Bass.

Nass, C., \& Mason, L. (1990). "On the Study of Technology and Task: A Variable-Based Approach." In J. Fulk \& C. W. Steinfield (Eds.), Organizations and Communication Technology, (pp. 46-68). Newbury Park, CA: Sage.

Nulty, P. (1995). "Why You Can - And Should - Wait to Get on the Internet." Fortune, 26 June, 148.

Orlikowski, W. J. (1992). "The Duality of Technology: Rethinking the Concept of Technology in Organizations." Organization Science, 3 (3), 398-427.

Orlikowski, W. J., \& Robey, D. (1991). "Information Technology and the Structuring of Organizations." Information Systems Research, 2 (2), 143-169.

Pfeffer, J., \& Leblebici, H. (1977). "Information Technology and Organizational Structure." Pacific Sociological Review, 20 (2), 241-261. 
Rasmussen, J. (1996). "The Internet - The Swiss army knife of business tools." CMA Magazine (March), 11-13.

Rice, R. E., More, E., \& D’Ambra, J. (1995). "Cross-Cultural Comparison of Organizational Media Evaluation and Choice (Draft Version), Working Paper: Rutgers University.

Robey, D. (1977). "Computers and Management Structure: Some Empirical Findings Reexamined." Human Relations, 30 (11), 963-976.

Robey, D. (1981). "Computer Information Systems and Organization Structure." Communications of the ACM, $24,679-687$.

Robey, D. (1995, ). Theories that Explain Contradiction: Accounting for the Contradictory Organizational Consequences of Information Technology. Paper presented at the ICIS, Amsterdam.

Rogers, E. (1983). The Diffusion of Innovation. (3rd ed.). New York, NY: Free Press.

Sale, K. (1995). Rebels Against the Future: The Luddites and Their War on the Industrial Revolution. New York, NY: Addison-Wesley. (as reviewed by J. Katz in Wired, 3.06, pp. 162-165, 210-220.)

Sarna, D. E. Y., \& Febish, G. J. (1996). "Intranets on the Runway". Datamation, 1 June 1996, 21-22.

Scotland, R. (1995). "Companies tread lightly." The Financial Post, 29 April, p. C13.

Scott, W. R. (1990). "Technology and Structure: An Organizational Level Perspective." In P. S. Goodman \& L. S. Sproull and Associates (Eds.), Technology and Organizations, (pp. 109-143). San Francisco: Jossey-Bass.

Sproull, L. S., \& Kiesler, S. B. (1991). Connections - New Ways of Working in the Networked Organization. Cambridge, MA: MIT Press.

Sproull, L., \& Kiesler, S. (1986). "Reducing Social Context Cues: Electronic Mail in Organizational Communication." Management Science, 32 (11), 1492-1512.

Stanfield, G. G. (1976). "Technology and Organization Structure as Theoretical Categories." Administrative Science Quarterly, 21 (3), 489-493.

Stewart, T. A. (1994). "Managing in a Wired Company." Fortune, 130 (11 July), 44-56.

Swanson, E. B., \& Ramiller, N. C. (1993). "Information Systems Research Thematics: Submissions to a New Journal, 1987-1992." Information Systems Research, 4(4), 299330.

Tapscott, D., \& Caston, A. (1993). Paradigm Shift: The New Promise of Information Technology. New York: McGraw-Hill.

Thach, L., \& Woodman, R. W. (1994). "Organizational Change and Information Technology: Managing on the Edge of Cyberspace." Organizational Dynamics, 30-46.

Thompson, J. D., \& Bates, F. L. (1957). "Technology, Organization, and Administration." Administrative Science Quarterly, 2, 325-342.

Trist, E., \& Bamforth, K. W. (1951). "Some Social and Psychological Consequences of the Longwall Method of Coal-Getting." Human Relations, 3 (4), 3-38.

Verity, J. W., \& Hof, R. D. (1995). "Planet Internet". Business Week, 3 April, 118-124.

Violino, B. (1996). "The Biggest and the Best". InformationWeek, 9 September, 44-46.

Weinman, L. (1996). Designing Web Graphics: New Riders.

Wilder, C. (1996a). "The Net on the Edge". InformationWeek, 29 April 1996, 36-37.

Wilder, C. (1996b). "The Web 'Ads' Up". InformationWeek, 5 August 1996, 41-52. 
Williams, F., \& Rice, R. E. (1983). "Communication Research and the New Media Technologies." In R. N. Bostrom (Ed.), Communication Yearbook 7, (pp. 200-225). Beverly Hills, CA: Sage.

Woodward, J. (1965). Industrial Organization: Theory and Practice. London: Oxford University Press.

Zeffane, R. (1989). "Computer Use and Structural Control: A Study of Australian Enterprises." Journal of Management Studies, 26 (6), 621-648.

Zmud, R. W. (1984). "Design Alternatives for Organizing Information Systems Activities." Management Information Systems Quarterly, 8 (June), 79-93.

Zuboff, S. (1988). In the Age of the Smart Machine. New York: Basic Books. 